\title{
Campus Law: Berkeley Viewed From Eugene
}

\author{
Hans A. Linde* \\ I \\ INTRODUCTION
}

College studENTs, their management, mismanagement, and unman-
ageability, have become news, and not only in Berkeley. Few universities, of course, would wish to contest the popular preeminence, commensurate with its standing in many other fields, that "Berkeley" has achieved as the national model and evocative word for trouble on the modern campus. ${ }^{1}$ It is no sense of competition that suggests an article on student conduct at the University of Oregon might be of interest in a symposium on "Berkeley." Nolle contendere.

But a look across the fence may sometimes be instructive, or at least take the mind off one's own troubles. During the year before "Berkeley," the University of Oregon had lived through the first months of experience with its new faculty-drafted, faculty-administered Student Conduct Code. While the new activism was moving Berkeley toward another explosion in the University of California's perennial struggle to bottle up its own constant spectre, politics, different student activities in Eugene had tested the University of Oregon's system of campus law-and its nerve.

True, the disciplinary preoccupations at Oregon-often in the conventional areas of cheating, sex, and liquor-have an old-fashioned air that may not fully engage the attentive sympathy of California students and instructors battling the establishment for free speech. This is not entirely the fault of their colleagues in Oregon. They, too, strive against anonymity, alienation, and anxiety in the multiversity, on a scale befitting a modest northern outpost. Oregon students collect civil rights funds for Mississippi, and many have gone South themselves; Oregon has Viet-

* B.A., 1947, Reed College; LL.B., 1950, University of California, Berkeley; Professor of Law, University of Oregon. During 1964-65, Mr. Linde, a forner editor of this Review, was Visiting Professor of Law at Boalt Hall.

1 Thus Esquire pictured the rebellious college student of 1965 as a comic strip liero, "Cal Kid," with an article called "Notes From the Berkeley Underground." Esquire, Sept. 1965, pp. 81-85. Fortune, describing the startling changes on the college scene in two thoughtful articles on the University of California, reported that "some students summoned to a dean's office were bringing their lawyers with them." Fortune, Sept. 1965, pp. 130, 131. See also Fortune, Oct. 1965, p. 140. But the Atlantic, true to its name, managed to construct a twelvearticle special supplement on "The Troubled Campus" without "Berkeley." The Atlantic, Nov. 1965, pp. 107-60. Hardly a general magazine during 1965 failed to take some notice of the topic. 
nam protests and teach-ins; Oregon has Gus Hall speaking to eleven thousand in the football stadium and brings religious speakers to the campus. The trouble is that Oregon has no rules against any of this. ${ }^{2}$ The University's president regularly exhorts its students to become committed, engagé. Admittedly the risk is smaller; the students, though a large number of the freshmen sport blue-and-gold sweat shirts marked "University of Cahifornia at Eugene," are not those of Berkeley. True, this seeming libertarian utopia once declined to continue publishing a literary magazine when its poetry caused public offense-but again, even a demonstrative protest reading of $H o w l$ in the center of campus failed to bring martyrdom either to students or to teachers. So where is the interest?

If there is one lesson to be learned from the University of California's experience with its rules, it is that no public university las any businessin law or in tactical common sense-making rules for its students ${ }^{3}$ restricting political activity as such. Even general and neutral rules may come under great legal stress when applied to conduct arguably protected by constitutional guarantees. But explicitly political campus rules cry out to be first tested for the full extent of their elasticity, then cliallenged head-on. Rules by public entities that in terms express concern with political behavior are prime candidates for instant unconstitutionality.

When the Berkeley bottle blew its stopper, administrators and faculty, regents, students, and assorted kibitzers at once plunged into debate over the wording of new rules for political behavior that would be, among other things, constitutional. About that, the preceding paragraph says nearly all this article intends to say. But the aftermath of the explosion also revealed that much more than the heady issues of free speech, fair and foul, is involved in designing campus regulatory machinery that can operate with the confidence of both the public and students. In early 1965

2 University of Oregon policy on "Off-Campus Speakers" is stated as follows: "A university is by definition a place of free inquiry. Without freedon to seek information in the library, in the classroom, in the laboratory, in field studies, and in the words of campus speakers, the objectives of a university cannot be achieved. In accordance with this basic principle of freedom to seek information wherever it may be found, the University of Oregon makes this specific statement of policy witl respect to the appearance of campus speakers who are not members of the University community: 1) Any faculty or recognized student group niay invite to the campus any speaker the group would like to liear;2) The appearance of an invited speaker on the campus does not involve an endorsement of his views by the University. (Adopted by the University Faculty March 7, 1962.)" UNIVERSITY of Oregon, Faculty HandBoor 21 (1965). No trouble with restrictive application has yet caused the reference to "recognized student group" to be controversial, as it would be in Berkeley.

3 Employees of the University of Oregon, including teachers, are apparently restricted by a general corrupt practices act from contributing to any candidate's campaign funds, ORE. REV. Star. \$ 260.230 (1965); but employees in public education may and do run for and hold elective offices. ORE. Const. art. XV, § 8 (1965). 
the University of Oregon, whose brave new Code had been on the defensive at home, began to get requests for scores of copies from the Bay Area and points South. It is interesting to speculate what might have been if Berkeley's code had reflected the principles of faculty-student participation in making the rules and in adjudicating violations, of substantive coverage limited to University responsibilities, and of strict adherence to stated rules and procedures, that could be read in those copies of the University of Oregon's.

This is an account of the Student Conduct Code of the University of Oregon. Readers interested in general reflections on the problems of student rights, rather than in that Code's attempted solutions, will find such reflections at the conclusion of the article.

\section{A. History of the Oregon Student Conduct Code}

In 1962 the management of student discipline at the University of Oregon corresponded to familiar patterns. In their substance, the "rules" of belavior enforceable by disciplinary agencies combined a hodge-podge of broad moral principle and petty detail with an accretion of campus traditions and social conventions. Their administration was primarily the responsibility of the several deans of students, of men, and of women, in the Office of Student Affairs; other roles were played by a Student Discipline Committee composed of deans, faculty, and students, by the dormitory management, and by subsidiary student groups. The published Discipline Code listed among grounds for expulsion such items as "Immorality," "Falsifying information concerning overnight off-campus privileges," and "Any action punishable under the State of Oregon Criminal Code." The hist of offenses leading to suspension ended with "Any other action that discredits the University of Oregon." The Discipline Code was by no means exhaustive. Elaborate additional rules for women students were issued by the official Associated Women Students organization, governing dress, study hours, and above all, the nocturnal separation of campus coeds from liquor and men. Other rules might be promulgated by special committees and by Greek-letter houses individually or collectively. ${ }^{4}$

During the 1962-63 academic year, the members of the tripartite Discipline Committee undertook a major reexamination of the philosophy;

4 The Discipline Code of the University of Oregon (1961). One report shows the Office of Student Affairs enforcing inter alia, "Serenade Regulations" and "Pledge Class Walkouts," the Student Activities Committee responsible for "Dance Regulations," the Dormitory Policy Committee for "Basement Rules," bed checks, and dress standards in dormitories, the Associated Women Students for dress standards elsewhere. Sororities exercised within each house the jurisdiction accorded the University's own dormitories. Memorandum in file of $A d$ Hoc Drafting Committee (1963). 
in substance and in administration, of the existing discipline program. The product of this reexamination was a report to the University faculty that slrarply delineated a majority and a minority position on the assumptions of such a program. The issues concerming these assumptions encompassed the relationship of the University to its students, to their parents, and to the wider adult community.

The majority's conclusions were reported in the form of seven recommendations, eacli accompanied by a statement of "explanation and implications." In summary, the committee's most important theses were that the University's basic purpose is the transmission of knowledge and understanding and the development of intellectual and rational capacity; that character development is a hoped-for product of the capacity for rational cloice rather than an independent University objective; ${ }^{5}$ that the University should clearly distinguish disciplinary action to protect University functions from general law enforcement, and should treat students as being separately accountable to the two; that mature, responsible behavior should not be sought for women any more than for men by rules premised on immaturity and irresponsibility; and finally, that an appellate procedure be devised to assure due process where the sanction would disrupt the student's education, that is, expulsion, suspension, "suggested" withdrawal, or denial of registration. ${ }^{6}$ The dissenters differed primarily in defending a distinct University objective of "moral growth and character developnient" and the use of a "double standard" of special rules for women as acceptable bases for University disciplinary policies. All members agreed that these poticies should be the responsibility of a single committee operating under a new code.

In May 1963 the University faculty debated and adopted the recommendations. The task of drafting a new code was assigned to a committtee of three professors and two students. Though administration personnel participated only as advisers rather than as members of the committee, President Arthur S. Flemming took an active interest. In June he submitted to the faculty a memorandum stating the objectives that he believed the University's "student affairs program" should pursue.

5 "The essence of this recommendation is the assumption that 'moral growth" or 'character development' should not be included within the definition of the fundamental purposes of the University [to protect which justifies disciplinary sanctions]. . . . The present discipline code appears to be based on a different set of assumptions; namely, that the University has an all encompassing responsibility for the 'inorals' and 'character development' of the student." Student Discipline Committee, Umversity of Oregon, Report to the Faculty, Recommendation No. 1, April 15, 1963.

6 "Students need to be protected from well-intentioned, honest error as well as from the possibility of the inappropriate use of authority. At the present time, formal safeguards are woefully lacking ...."Id. Recommendation No. 5 . 
Largely consistent with the recommendations of the earlier Discipline Committee, the President's objectives included encouraging students toward "ethical sensitivity," independence, and inaturity; deterring interference with the educational objectives and related rights of other members of the educational community; recognition of the changing and increasingly varied composition of the student body; student participation in both the making and enforcement of rules of conduct; procedural rights; separation of University and community sanctions, with no special treatment for students "downtown" nor the substitution of University pressures for normal civil or criminal law enforcement. ${ }^{7}$

By devoting the summer to its assignment, the newly appointed committee presented the new Student Conduct Code to the faculty in October 1963. The Code was adopted by faculty vote and has been in effect since that academic year.

\section{B. The Legal Position of the University of Oregon Student Conduct Code}

Before turning to the substance of the policies and procedures embodied in the Student Conduct Code of the University of Oregon, it is worthwhile to give attention to the legal position of the University's disciplinary powers. This aspect is not only of special interest to the readers of a law review. It is also an inescapable precondition and limitation of any action taken by or in the name of the University, although this inconvenient fact is sometimes repressed into the institutional subconscious, to emerge only on occasions of acute crisis. The Oregon Code was drafted and has been administered with the participation at every stage of some member of the University Law School faculty.

In many respects the legal position of the regulation of student conduct at the University of Oregon is the same as at public colleges and universities generally. For purposes of the United States Constitution's constraints on state govermental agencies, in particular, it makes little difference how the laws of different states organize the management of public higher education. But the debate of student rights and educators' wrongs leaps too quickly into the constitutional arena. State law is important, not only because constitutional issues should be avoided when possible, but because state policy and its administration can be altered to take account of the state's and its neighbors' experiences. In two respects the Oregon Student Conduct Code reflects Oregon law.

7 University of Oregon, Memorandum from the President to Members of the Faculty, June 5, 1963. The memorandum also contained some cautiously phrased references to the most touchy parental concerns with housing rules after the freshman year and with equal treatment of men and women. 
The first of these is that the Code was an act of the University faculty, not by administrative grace, but by law. The statute creating the University of Oregon, first enacted in 1876, begins with the sentence: "The president and professors constitute the faculty of the University of Oregon and as such have the immediate government and discipline of it and the students therein ... . " Under this statute no power of discipline is lodged in the president separately, but rather jointly in him and the "professors" together constituting the faculty. President Flemming's participation in the formulation of the Code followed the spirit as well as the letter of this law.

Second, the University of Oregon is a state agency subject to the Oregon Administrative Procedure Act. This statute, enacted in 1959, in general follows the provisions of the Model State Administrative Procedure Act to prescribe procedures for the adoption and publication of administrative rules and the decision of "contested cases" by all nonexcepted state agencies. ${ }^{10}$ There is not yet any authoritative interpretation applying these prescriptions to rules and decisions affecting students within Oregon's state system of higher education. But the Oregon A.P.A.'s definition of "rule" leaves little doubt concerning University regulations that govern admission, expulsion, suspension, or other signifi-

8 ORE. REv. StAT. § 352.010 (1965).

9 The word "professors" has been interpreted through the years to encompass the lesser academic breeds within the law. The University of Oregon faculty legislates only in meetings of the whole. The president by statute is also president of the faculty, as well as "executive and governing officer of the school, except as otherwise provided by statute." ORE. REv. STAT. $\S 352.020$ (1965). The University is one of seven institutions under the administration of a single State Board of Higher Education of nine directors holding no other political offices, and appointed by the governor, with consent of the senate, for overlapping six year terms. In administrative structure and in practice, the Oregon system of higher education might be viewed essentially as the model for the Byrne study's recommendations for the University of Cahifornia. See Byrne, Report on the University of California and Recommendations to the Special Committee of the Regents of the University of Califorma, May 7, 1965. Legally, the board is empowered to manage the finances and property of the institutions, appoint personnel, set admission requirements and fees; and it may "for each institution ... (b) Enact rules and bylaws for the government thereof, including the faculty, teachers, students and employees therein." ORE. REv. STAT. \$ 351.070 (1965). With respect to the University, this general grant of power nust be applied consistently with the specific statutory section on discipline, $\$ 352.010$, quoted supra note 8 . To avoid any question of improper delegation, the Umiversity Student Conduct Committee's authority is expressly derived both from faculty legislation and presidential delegation. See Student Conduct Code I.E.1, Appendix infra.

10 ORE. REv. STAT. §§ 183.310-.510 (1965). see Hazard, The Oregon Administrative Procedure Act, 39 ORE. L. REv. 97 (1959). Rule-making is required, "as far as practicable," to include advance notice and opportunity to suhmit views, followed by publication of rules adopted in a prescrihed administrative bulletin. ORE. REv. STAT. $\$ \$ 183.330,350-370$ (1965). The decision of a "contested case" nnust be based on a record made in a prescribed, quasijudicial administrative hearing including reasonable notice, counsel, subpoenas, evidentiary limitations, and written findings. ORE. REv. STAT. §§ 183.420-.470 (1965). 
cant benefits and penalties. ${ }^{11}$ Less certain is the applicability of the Act's adjudication procedures to student disciphine cases. The Act prescribes procedures only for hearings that are otherwise "required by statute or constitution," and for license deprivations. ${ }^{12}$ Thus the constitutional standard for the requirement of a hearing is itself made the statutory standard. Some disciplinary actions may not rise to a level at which due process requires a hearing, but withdrawal of the valuable public benefit of college education by disqualification, expulsion, or suspension must meet fourteenth amendment standards. ${ }^{13}$ When a hearing is constitutionally required, however, the procedures prescribed by the Oregon A.P.A. are those of the Act itself, even though something less would satisfy the constitutional minimum. Thus there is no legal basis on which an Oregon state agency can simply decide to satisfy what it deems to be minimum constitutional standards of fair procedure in determining individual rights, duties, or privileges; it may use such minimal fair procedures only when it claims that no hearing is constitutionally required at all.

The University of Oregon did not squarely resolve on what legal premise it would act. It chose to design disciplinary hearings that would duplicate the procedural rights of the A.P. A. to the fullest extent possible in a system of campus tribunals, and hope that the fairness of the system would postpone indefinitely a legal challenge to any respect in which it might depart from the exact A. P. A process. ${ }^{14}$

11 " 'Rule' means any agency order, directive or regulation: (a) The violation of which subjects the person violating the same to imposition of a penalty. (b) Establishing, altering or revoking any procedure, practice or requirement relating to agency hearings at which specific parties are entitled to appear and be heard. (c) Establishing, altering or revoking any qualification or requirement relating to benefits or privileges to which applicants are entitled by law ... ." Ore. Rev. Stat. \$ 183.310(3) (1965). The final word "law" should be read to include not only statutes but also regulations carrying out statutory programs, sueb as those of the state system of higher education, since by the very lyypothesis of this subsection the "qualifications or requirements" are fixed administratively rather than in the statutes. When the A.P.A. means "statute" it uses that word. ORE. REv. STat. $\$ 183.310(2)$.

12 " 'Contested case' means a proceeding before an agency in whicl the individual legal rights, duties or privileges of specific parties are required by statute or constitution to be determined only after an agency hearing at which such specific parties are entitled to appear and be heard and shall include in all cases proceedings for the suspension, revocation or refusal to renew of hicenses required to pursue any commercial activity, trade, occupation or profession where the licensee demands such a hearing." OrE. REv. STAT. \& 183.310 (1965).

13 See Dixon v. Alabama State Bd. of Educ., 294 F.2d 150 (5tl Cir. 1961); cf., with respect to comparable public benefits, Flemming v. Nestor, 363 U.S. 603 (1960) (fifth amendment applicable to social security benefits); Sherbert v. Verner, 374 U.S. 398 (1963) (fourteenth amendment protects unemployment benefits). The bibliography in this issue lists several thorough studies of the procedural riglits of college students.

The constitutional standard incorporated into the Oregon A.P.A. is the federal fourteenth amendment. The Oregon state constitution does not have a "due process" or equivalent clause that would require admimistrative learings.

14 Existing short-cuts, largely in connection with verbatim records of testimony, written 
II

\section{THE STUDENT CONDUCT CODE}

The developing public reexamination of the roles and the rights of college students can find much of interest in the characteristics of the Student Conduct Code ${ }^{15}$ that emerged from this background, and in the record of its operation at the University of Oregon during its first two years. Rather than stram the bounds of space and reader attention by a seriatim analysis of its provisions, this article will describe first the structure of the Code and its admimstration, and then the chosen solutions for a number of the key problems in designing a student conduct system and the early experience with those solutions.

\section{A. The Structure}

The document generally, though loosely, called "the Code," which tells the student under what conditions the University of Oregon may penalize him (outside the academic demands of the classroom), actually consists of three parts: "The Code of Student Conduct," "The Administration of the Code," and "Rules and Regulations." This structure results partly from the intrinsic content, partly also from the solution chosen for the practical problems of stability and change, of faculty action on fundamentals and delegated authority for adaptation.

What was submitted to the faculty in October 1963 included the Code, adopted by faculty vote, and the Administration of the Code. The Code established "General Policies," "Violations," "Sanctions," the Student Conduct Committee and the Student Court, and the records system. The Code can be amended only by faculty action (I.H.1); but it delegates to the Student Conduct Committee authority to adopt additional rules and sanctions for violations below the level of interruption of the student's rights to university attendance (I.B.3.f, I.C.1.f), to establish minor tribunals of students (I.F.2), to supervise enforcement procedures, hear individual cases, and other functions (I.E, I.G). The Administration of the Code, Part II of the docunent, encompasses provisions for the Student Court and for a special Associate Dean of Students (II.A), for minor courts including a traffic court (II.B,C), and the procedural sec-

waiver of oaths, detailed findings of fact, and similar documentation, are matters of personnel and expense that can be provided for whenever legally required.

15 Due to careless editing, the Code is variously labeled the Code of Student Conduct, the Student Code, or the Student Conduct Code, this last being the accepted usage. The most important provisions of the Code and its subsidiary documents are printed as an appendix to this article. The full current text can be found in the University of Oregon Student Handbook for each academic year. Citations to paragraphs of the Student Conduct Code in the text and footnotes of this article will be indicated parenthetically. 
tions governing investigation, charge, hearing, and appeal. Part II differs in being subject to amendment by the Student Conduct Committee (II.G), within limits consistent with the Code; and much of it, especially the detailed hearing rules and the minor court system, are in fact the work of the Committee. Part III of the document consolidates in one place the substantive rules adopted by the Student Conduct Committee under the himited delegation stated above; here are the rules dealing with dormitories and other University-related hiving quarters, and with dances and other social activities.

The institutional structure of the system draws upon participation by faculty members, students, and administrative staff so as to balance the various requirements of the law, of student involvement, and of administrative practicahty. The Student Court consists of five students and two faculty members. ${ }^{16}$ The Student Conduct Committee, which holds the delegated rule-making and final judicial authority, consists of a faculty majority of four with three student members, similarly appointed by the President. ${ }^{17}$ The most striking innovation in the administration of the Oregon program is that the deans in the office of student affairs have been relieved of their previous disciplinary duties. Critics of the conventional arrangements before the Code maintained that it was undesirable to mix the functions of counseling and advice with that of discipline. Riglitly or not, students seemed to feel that a dean's inquiry mto any troubled situation might indeed be with the kindest intention to help, but then again might lead to disciplinary action, with the choice of the use to be made of information obtained from students lying in the personal discretion of the deans. The decision for or against this combination of functions presents the most graphic illustration of the choice between the parental and the administrative analogy for the universitystudent relationship. In the design of the new procedures, President Flemming insisted that no sanctions be imposed upon the order of any administrative officer..$^{18}$

Administrative functions under the University of Oregon Student Conduct Code are performed by a new Associate Dean of Students. This associate dean serves as secretary of the Student Conduct Committee (I.E.3), collects and presents the information on which charges are based

16 The student members are appointed by the President of the University upon the reconmendation of the student body president. They serve staggered two-year ternus. The Code provides that "Whenever possible, one member shall be a second or third-year law student" (II.A.1). The law student has often been elected as the presiding chairman of the court. Law students also often represent defendants before Code tribunals.

17 President Flemming has consistently made all faculty committee appointments upon recommendation of the faculty committec on committees.

18 Minutes of the Drafting Committee, Sept. 18, 1965. 
and serves notice of the charges on the student concerned (II.A.7,8,10.b; II.D); but he does not sit in on the deliberation and decision of any case after the hearing (II.A.8). He also has the option to refer cases to public law enforcement agencies or to medical or psychological counseling processes instead of University discipline. He and his office are responsible for assuring that all records and reports required under the Code are properly made and filed (I.E.6, I.G, II.D.7). To avoid overloading the Student Court, minor courts composed of students have been provided for campus traffic violations and for handling most of the less serious infractions; in the dormitory blocks limited disciplinary authority has also been delegated to resident counselors. None of these can impose a sanction interrupting a student's educational status, and their decisions are appealable (II.B).

\section{B. The Problem of Law Violations.}

The relationship between the sanctioning powers of the public university and the enforcement of general community laws occupied more time and attention in the design of the new program than any other problem. The legal, philosophical, and practical questions raised by this relationship are inescapable and inust be faced in any institution. At Berkeley they proved to be the crux of the debate over student participation in off-campus demonstrations, civil disobedience, and other politically motivated actions that might result in valid convictions under criminal laws, a debate in whicl some raised the cry that the students were seeking to use the campus as a privileged sanctuary, a "fortress" from which to "mount unlawful actions." 19 But the problem only exceptionally involves issues of pohtical action and first amendment rights, nor is it one peculiar to universities. ${ }^{20}$ In the preparation of its Student Conduct Code, the University of Oregon tried to identify a principle that could serve as the controlling premise for adding or withholding university sanctions in matters covered by general law.

The old Discipline Code, probably without any conscious concern with the question, had followed conventional lines and included, among grounds for expulsion, "any action punishable under the State of Oregon

19 See McClosky, Statement on Academic Senate Resolution of December 8, 1964, in The Berkeley Student Revolt 257, 263 (Lipset \& Wolin eds. 1965); cf. Statement by President Clark Kerr, California Monthly, Feb. 1965, p. 88 (statement of December 3, 1964).

20 The question of whether and when to use internal sanctions against individuals for misconduct under general "outside" laws also faces, for instance, the armed forces with respect to various off-duty delinquencies of servicemen, and industrial organizations with respect to their employees. A recent case illustrating the use of court-martial for essentially non-military misconduct, as well as the issue of procedural rights (right to counsel) in such trials, is Application of Stapley, 246 F. Supp. 316 (D. Utah 1965). 
Criminal Code."21 This rule on its face potentially exposed students to loss of their educational status as an additional sanction for any law violation whatever. But the special status of students also had another side. Faculty critics of the old system were especially hostile to the practice of the community to look to the University to "take care of" a student who "got into trouble." If the police arrested an intoxicated student for reckless driving, if a merchant had a student shoplifter or rubber check artist on his hands, if irate parents charged some campus Lothario with attempted or completed statutory rape, their decision to invoke or not to invoke the normal processes of civil or criminal law enforcement should not be affected by the extraneous fact that the miscreant happened to be enrolled at the University, where a dean might discretely persuade him to dispose of his car, to pay his debt, or perhaps remove him from the community. Defenders of the old order argued that in the case of University students more than other people, a court record might blight a promising career in which society had invested much. This argument could not withstand objections that the University ought not be party to social discrimmation in law enforcement on behalf of a favored class, that the real pressure for the protective practices was not concern for students but the University's own public "image" and the respectability and social position of students' parents, and that the Umiversity could not collaborate in this informal system of substitute law enforcement without thereby making itself responsible to police its student body. The result was a clear-cut rejection both of any informal privileged status for University students and of any concomitant University responsibility as community police agency.

The principle adopted as the controlling premise of the new Student Conduct Code was that the University of Oregon would use disciplinary sanctions only to protect specified interests of the University community itself. The principle is spelled out in the opening sections of the Code itself, under the heading "General Policies."22 Paragraph A.2 states the negative that the University "will not request or agree to" special legal consideration for students as such and will not use University sanctions as additional punishment after legal prosecution. The positive criterion of all disciplinary rules appears in paragraph 3:

The University may apply sanctions or take other appropriate action only when student conduct directly and significantly interferes with the University's (a) primary educational responsibility of ensuring the opportunity of all members of the University commumity to attain

2I The Discipline Code of the University of Oregon, art. I, \& 8 (1961). In practice the deans had used the sanction of suspension rather than expulsion.

22 See Appendix infra. 
their educational objectives, or (b) subsidiary responsibilities of protecting the health and safety of persons in the University community, maintaining or protecting property, keeping records, providing living accommodations and other services, and sponsoring non-classroom activities such as lectures, concerts, athletic events, and social functions.

This restrictive criterion for all disciplinary action governs the promulgation of substantive rules by the Student Conduct Committee; it also controls the applicability of rules to particular cases. ${ }^{23}$ Obviously this involves debatable and difficult issues of drawing borderlines for the University interest. Yet in large measure it is clear what student conduct is included and what is excluded. A student may be suspended for stealing a book from a fellow student or the library, but no longer for slioplifting it downtown; in that case, criminal prosecution is exclusive. $\mathrm{He}$ will face University discipline for forging a University document but no longer for passing a forged check to a merchant. A tavern brawl is for the police, unless another student is a victim.

Among the stated University responsibilities, interference with which is made a precondition for any University discipline, some may seem to offer the conduct committee a tempting elasticity under the pressure of an external crisis or particularly indefensible episode. Yet fairly read, these

23 Thus, in the Code's list of violations, those which are not by their nature confined to the University setting are so confined in terms, for example, "Theft occurring under the conditions of paragraph A-3," "Disorderly conduct . . occurring under the conditions of paragraph A-3." (I.B.2.f; I.B.3.b)

With the Oregon Code's requirement of explicit rules, premised upon an identified University concern, and excluding law enforcement as such, compare the University of California's opening statement of General Policy on Student Conduct and Discipline: "It is taken for granted that each student has an earnest purpose and studious habits, and that he will adhere to acceptable standards of personal conduct; and that all students and student organizations will set and observe among themselves proper standards of conduct and good taste, obey the laws of the State and community, and conduct their social and other activities in a manner compatible with the educational purposes of the University. This presumption in favor of the students and their organizations continues until, by neglect of academic duty, or by misconduct, it is reversed, in which case the University authorities will take such action as the particular occurrence judged in the hight of the attendant circumstances, may seem to require. Students and student organizations which fail to make proper use of the opportunities freely given to them by the University nust expect to have their privileges curtailed or withdrawn." University of Califormia, Policies Relating to Student Conduct and Discipline (June 29, 1961), reprinted in Califorma Montuly, Feb. 1965, p. 79.

This circumlocution-stated as a prediction of University "action" in case a "presumption" of "acceptable standards of personal conduct ... good taste" and obedience to law, first "taken for granted," is "reversed," rather than as a rule-nevertheless served as a direct source of discipline. Apparently the leaders of the initial violations of Berkeley's card-table rules were suspended on a charge of "misconduct." Report of the Ad Hoc Committee on Student Con$d u c t, i d .82,83$. This statement of general policy on student conduct has now been superseded by $\$$ II, part A, of the University of California Policies Relating to Students and Student Organizations, Use of University Facilities, and Non-Discrimination, effective July 1, 1965. 
stated grounds express a coherent and delimiting definition of the University's responsibilities. And it is important to take note of what is not included. There is no mention of interference with the University's public "image." Rules of student conduct will not be justified by the need to protect the University against criticism. Gone is the old Discipline Code's conventional catch-all threat of suspension for "any other action that discredits the University of Oregon." ${ }^{24}$ When confronted with a civil or criminal offense, the direct impact upon the life of the University community, not the mere fact that the misconduct is charged against a student, is the test of the University's concern under the new conduct program.

\section{The Problem of Coverage}

The decision expressed in paragraph A.3, to confine University disciphine to misconduct invading a specific University interest, furnished a philosophy but not in itself a rule of conduct. Two other principles familiar to lawyers governed the preparation of the Code: First, that no penalty should be imposed except for violation of a pre-existing rule; and second, that all rules must be published in readily accessible form and be sufficiently precise, both to control discretion and to let students know the extent of their hability to discipline. If A.3 is the philosophical heart of the Code, its legal backbone is paragraph B.1: "No sanction or other disciplinary action shall be imposed on a student by or in the name of the University except in accordance with this Code."

Adoption of this fundamental notion for institutional discipline imposed burdens not only on administrators and tribunals but also on those responsible for legislating the substantive content of the Code. The codifiers had to recognize that student misconduct, however reprehensible, would not meet with University sanctions unless within the terms of their rules, and they were denied the easy escape of any general "good conduct" language that would rob students in one clause of the certainty and fair

24 The Discipline Code of the University of Oregon, art. II, $\S 7$ (1961).

A perversion of the University's responsibility to maintain its educational functions, as stated in paragraph A.3 of the new code, would be the argument that the University may and should impose student rules to protect its political caparity, as a tax-dependent institution, to perform those functions-a view sometimes seriously held and defended by academic "realists" as well as administrators at Berkeley and elsewhere. Neither experience at the University of Oregon generally nor the legislative history of the Student Conduct Code supports any misgivings of such a reversal of the code's concept of academic responsibility.

Of course, university apprebension of pubbic or pohtical reaction could in any case not justify infringement of students' constitutional rights; one state agency cannot plead fear of another state agency or of the electorate in defense of such infringement. Cooper v. Aaron, 358 U.S. 1 (1958). See also Evans v. Ennis, 281 F.2d 385, 389 (3d Cir. 1960); State ex rel. Hawkins v. Board of Control, 83 So. 2d 20, 24 (Fla. Sup. Ct. 1955), cert. denied, prior decision vacated and remanded, 350 U.S. 413 (1956). 
notice apparently granted by the other. Problems of coverage included difficulties in stating not only the conduct forbidden, but also the territorial limits or other conditions constituting the necessary nexus with the University's responsibilities.

The original draftsmen placed in the Code three lists, exclusive until amended: one of offenses that might result in expulsion or suspension (I.B.2), one of offenses liable to lesser penalties (I.B.3), and one of sanctions (I.C).$^{25}$ The list of serious violations concerns primarily the preservation of academic honesty, University records, and security of persons and property; additional grounds for disciplinary interruption of academic status can be created only by action of the faculty. Of violations leading to probation and loss of privileges without such interruption of status, the Code itself lists offenses concerning alcohol and living quarters insofar as related to the University; otherwise the elaboration of sucl lesser violations is left to the Student Conduct Committee (I.B.3.f) ${ }^{23}$ The Committee also has authority to add to the list of "lesser sanctions" than expulsion or suspension. ${ }^{27}$

The problem of territorial coverage is easy where the offense is directed at University records or property or is confined to campus buildings or "University-related" housing and living organizations (predominantly fraternities and sororities). The other key concept delimiting the required nexus, that of the "University community," is undefined in the Code. Besides the University's students, faculty, and staff, this community undoubtedly encompasses visiting speakers, athletic teams or

\footnotetext{
25 For complete text, see Appendix infra.

26 To be enforced under this section, committee-approved rules must be "published, distributed, or posted in such manner as to furnish adequate notice of their contents to students affected by such rules. The Umiversity's failure to comply with this requirement shall be a complete defense to any charge of violation of a rule of which the student has no actual knowledge." (I.B.4)

Rules made by any University official, committee, or student group, to be enforceable by Code sanctions, "nust be submitted to the Committee for approval" and become "effective fifteen days after filing with the Secretary of the Committee unless disapproved, within this period ....." Even professional draftsmen of new legislation make mistakes, and a code produced by the faculty committee process is even less immune froml errors and oversights. Thus it appears, textually, as if the "complete defense" of nonpublication can be circumvented if a rule was not approved by the Student Conduct Committee but merely submitted to it by the initiating agency and not disapproved within fifteen days. Moreover, pohcy assumptions about participation by students or other interested persons in rule-making through notice and opportunity to submit views, familiar in all administrative reform legislation and stated in A.5, were not expressed by inclusion of any rule-making procedure in the text. The Code text and the need for possible amendments are currently under review by the Student Conduct Committee.

27 The Student Conduct Committee has authorized the minor courts to impose "sanctions involving the rendition of labor or services. ... where principles of restitution or rehabilitation render such type sanctions peculiarly appropriate." (II.B.I)
} 
other students from another school, audiences and guests at campus cultural or social events, perhaps any visitor invited in connection with University functions. Inclusion of the offense of "vandalism or kidnapping committed on other campuses" (I.B.2.g) suggests that it extends to relations with a larger academic community. Beyond this lie, at first, hypothetical speculations and, soon, the accretion of case-by-case experience. Presumably the concept does not stretch out to reach alummi and the parents, spouses, or other relatives of students or staff in situations otherwise unrelated to specified University concerns.

On the other hand, coverage is not determined by searching the title to real estate, as sometimes appears to be the case at the University of California. ${ }^{28}$ The Umiversity of Oregon carnpus has no gates. Its build-

28 At Berkeley, much has been made of the hine between the paved, open area in front of Sather Gate and the public sidewalk of Bancroft Street (and similar lines at other entrances). The Berkeley crisis in the fall of 1964 was triggered by the announcement that University of California rules against the use of its property for political solicitation and advocacy of offcampus "pohitical or social action" would be enforced against distribution of hterature from card tables in the contested twenty-six foot strip of sidewalk. See letter from Dean of Students to student organizations, Sept. 14, 1964, California Monthly, Feb. 1965, pp. 35-36; Report of the Ad Hoc Committee on Student Conduct, id. at 82, 83. After the explosion, President Kerr told University of California alumni: "In September 1959, I suggested that a twenty-six foot strip be returned to the City of Berkeley. The Regents approved this by a vote of 15 to 2 ; but the transfer was never formally made, although many of us thought it had been. It was on this twenty-six foot strip that political action became more and more intense until in September, 1964, the Berkeley campus felt it necessary to ban such activity." A Message to the Alumni from President Kerr, id. at 94. Apparently the administration felt this ban to be compelled in spite of the Regents' vote, because the legal transfer of property between the two pubhic agencies had not been formally consummated. And compare, clsewhere in the present symposium, the references to Berkeley debates over the regulation of student pohtical activity "on-campus" or "off-campus," with the key concept of "campus" taken for granted and left largely unexamined.

Yet where University interests other than protection of tangible property are concerned, and especially political freedom, property boundaries are hardly the relevant measure of the "campus." Consider these concrete examples: The state university buys adjacent residential property for future expansion; pending its use, some of the homes are occupied by existing tenants, some rented to married students, some razed and the land temporarily landscaped or paved for parking. Campus? Unable to meet all freshman housing needs from public financing, the university encourages the construction of a wholly privately owned and managed dormitory, occupied exclusively by unmarried students. Campus? The university builds an athletic stadium a mile from its academic areas, on land owned by it, as part of and sharimg access and parking with a cultural center complex developed in collaboration with local government in the midst of a large, open public park. Campus? Pending the construction of new academic facilities, the university rents space in various privately owned office and business buildings around town for classes, administration, student cafeterias, and lounges. Campus? The university, with its administrators, academic personnel, and special staff, operates a pre-college level training center under federal contract in a federally owned former military camp. Another state university houses faculty and students at an institute of oceanography on the beach, a forest research center in the woods, whole square miles of agricultural experiment stations. What coverage here for "campus" regulations? Yet even the conventional academic campus, such as the central part of 
ings, lawns, playing fields, dormitories, and the nearby fraternity and sorority houses front on public streets, open to anyone without inquiry about his business "on campus." With modern college students increasingly residing or spending mucl of their time away from the campus, a student conduct program inescapably must sort out conduct "at the University" from that which is not. The Code's concept of the University community takes meaning from the basic focus on the University's functions rather than on its grounds.

\section{The Problem of Exclusiveness}

Under the head of "coverage" might also fall two other problems that were raised by the adoption of the Student Conduct Code at the University of Oregon. One of these, the conduct of student groups, appears below in the story of the University's early experience under the Code. The other concerns the relationship of the Code to other University judgments and actions with respect to students.

This problem is illustrated by the Code offenses of clieating and plagiarisin, falsifying information and records, and abuse of University property. Are Code sanctions the exclusive response to sucli misconduct? A careful reading of the Code appears to make the solution reasonably clear. As in drawing some similar lines between civil and criminal procedures, it may be found in looking realistically for the presence or absence of punitive objectives. ${ }^{29}$ But this criterion is not sufficiently precise in practice to avoid touching some sensitive academic nerves.

Suppose an instructor, convinced that a familiar-looking composition has in fact emerged once again from the archives of the student's fraternity, imposes a grade of "incomplete" until the student submits an original paper. Suppose the University withdraws a scholarship because the date on a letter of reference was altered, or denies a student future readmission to the dormitories because of an established record of caus-

Berkeley's, may contain acres of park land that are in no functional way different from similar parks in other public ownership.

The question raised here is not merely how the "on-campus," "off-campus" distinction would deal with these situations; it is, rather, whether a theory of university discipline built on that distinction is tenable at all.

29 Compare, for instance, the controversies over the applicability of civil or criminal law concepts in In re Maddox, 351 Mich. 358, 88 N.W.2d 470 (1958) (sexual psychopath laws); People v. Frontczak, 286 Mich. 51, 281 N.W. 534 (1938) (sexual psychopath laws); People ex rel. Baxstron v. Herold, 14 N.Y.2d 490, 251 N.Y.S.2d 938, 202 N.E.2d 159 (1964), rev'd and remanded, 86 Sup. Ct. 760 (1966) (insanity commitment of convicted prisoner); White v. Reid, 125 F. Supp. 647 (D.D.C. 1954) (juvenile court commitment to detention); In re Holnes, $379 \mathrm{~Pa}$. 599, 109 A.2d 523 (1954) (juvenile court commitment to detention); Abel v. Umited States, 362 U.S. 217 (1960) (search and seizure); Ohio ex rel. Eaton v. Price, 364 U.S. 263 (1960) (search and seizure). 
ing excessive noise and disturbance, chronic friction with others, or perhaps more unfortunate grounds of unsuitability. The quick answer is that these academic or administrative decisions are not "sanctions" imposed for disciplinary reasons under the Code. Giving a bad check in payment of tuition will likely interrupt a student's education without a judgment of the Student Court.

Suppose, however, that a student, failed by his instructor for being caught cheating on an examination, is acquitted by the Student Court. Does the " $F$ " stand? The majority of teachers in practice prefer to use academic controls of cheating rather than bring disciplinary charges; may a student demand a "trial" on his own motion? The guarantee of the exclusivity of the Code in paragraph I.B.1 only protects students against any "sanction or other disciplinary action" outside the Code, and it may be taken for granted that in adopting the Code the faculty did not give up its prized academic control of the classroom and of evaluating student scholastic performance.

Nevertheless, students are understandably suspicious of sophistry in the use of adverse University actions against them outside the forms of "discipline." So the Student Conduct Committee faces the task of explaining to students the complexities of parallel lines of legal action and the limits of res judicata, familiar to lawyers in the analogies of civil, criminal, and administrative remedies for a single occurrence-and, even worse, explaining to professors that student performance may be downgraded for cheating or plagiarism only as far as seems scholastically justified, but not beyond this in pursuit of the teacher's own disciplinary views.

\section{E. The Problem of Records and Publicity}

A sigmificant source of student distrust of the old, conventional system of discipline was the opacity of its apparently ad hoc application to individual students, and the handling of student records. Although space does not permit a detailed description of the new system of records here, its design was one of the important tasks and achievements of the Code. The Student Conduct Committee is charged with providing reporting procedures for all disciplinary cases from all tribunals; the the Associate Dean of Students is responsible for maintaining these records (I.G; II.A.4). In practice, mimeographed forms have been worked out to be used in notifying students of hearings on charges against them and for reporting the decisions of the courts (II.A.10.a, e; II.B.8). These forms are designed to facilitate the maintenance of different files for the accumulation of precedents without identification of names, for the student's personal record, and for the records of the work of the 
system itself (II.D.7). The continued responsibility of the system to the faculty is assured by a Code provision for annual written reports by the Committee on all aspects of the student conduct program (I.E.7).

One familiar controversy has survived - the perennial conflict between the competing interests of a community to know its official processes and to protect the private affairs and reputations of its members. The Code provides that "a request by a student for a liearing closed to the public will be given due consideration" (II.A.7). Proceedings are open unless otherwise ordered ${ }^{30}$ Although reporters for the campus newspaper can and do attend hearings, and no obligation of secrecy is imposed on any participant in the process, editors and members of the Committee have with some effort established an informal modus operandi of not publishing names in reports of student conduct matters.

\section{F. Experience Under the Code}

No sooner had the new Student Conduct Code been put into effect at the University of Oregon than it had to meet its first and crucial tests. Adoption of the new system liad been met with suspicion and lostility by organizations of Mothers and Dads. Sucli impressions of the system as might be gained from reports by news inedia added up to a general sense of relaxation of University responsibility for watching over student beliavior, whicls to many inembers of such organizations means particularly responsibility for lousing rules, closing hours, and sexual behavior. The deans did little to reassure this constituency that their counseling influence would successfully survive their loss of disciplinary powers; some, in talks to parents' groups, predicted an early return to the good old days. Meanwhile the newly-appointed Student Conduct Committee spent long hours establishing the operational framework and drafting rules to complete the details of the system.

One early episode disclosed an unfilled gap. A fraternity dance had got out of land, rules against liquor in the house liad been ignored, a chaperoming adult had been treated rudely and, in fact, accidentally injured. Yet it was not possible to single out, identify, and discipline those among the members and guests (including some nonstudents) who had individually violated specific rules. The Student Conduct Committee, true to its charter, prosecuted charges only against one known defendant and then turned its attention to the difficult task of defining group responsibilities. The result was a new section of the Code dealing with "Group Offenses" (I.D).

30 University of Oregon Student Conduct Committee, Second Annual Report, 1964-1965, at 1 (1965). The Student Conduct Committee also rejected an amendment suggested by the Student Court that its hearings be open only on request of defendants. Ibid. 
The test adopted by the faculty for group responsibility is that "the group has encouraged or did not take reasonable steps, as a group, to prevent violations of law or University regulations." include suspension of charter, social probation, denial of University facilities, and the like; they inay be imposed only by the Student Conduct Committee after a hearing in which the group is represented by its principal officer. Proceedings against a group can have no disciphinary effect with respect to an individual..$^{22}$

In other ways the system has had to take account of the fact that the University recognizes organized student living groups. The fraternities and sororities establish and enforce rules for themselves in addition to the University's rules, both through their respective organizations and within each house. The Code establishes a strict separation between the enforcement of its own and any other rules; no tribunal enforcing the Code can have any other function than those delegated to it under the Code (I.F.3). Although the unofficial rules and committees of the Greek organizations thus cannot substitute for "minor courts" (and the Code tribunals, of course, do not enforce the Greeks' rules), the administrators of the Code in practice will exercise their discretion not to pursue routine cases of infractions of minor University rules when it is shown that these are being adequately handled as infractions under the parallel unofficial system..$^{33}$ Beyond this procedural modus operandi, many of the tough substantive issues of the University's disciplinary responsibility arise from the ambiguous position of organized living groups which, on the one hand, do not occupy University housing but, on the other, enjoy a degree of University recognition and cooperation without which they would not be able to recruit their annual replacements of young, lowerdivision students. When, to take the most pervasive problem, these minors are given alcohol at group social functions, Oregon law is violated whether or not house rules are, and the hypocrisy whereby the drinking is confined to "pre-functions" and parking lots outside the house becomes part of their introduction to the ethics of community living. ${ }^{34}$ When a group

31 Paragraph I.D.1 has recently been amended to remove the reference to "law" as being inconsistent with Code policy, and instead to define by rule the unlawful conduct meant to be covered.

32 "Nothing lerein authorizes the imposition of individual sanctions on any person other than in accordance with the Code of Student Conduct." (I.D.3)

33 The policy of the Student Conduct Committce with respect to the policing by the Interfraternity Council and Panhellenic of group offenses within their member organizations was reported to the faculty in the University of Oregon Student Conduct Committee, silpra note 30 , at 5 .

34 The Code probibits alcohol on University property, "in University related housing for single students, or at University sponsored or supervised functions," and "disorderly conduct resulting from drunkenness." (I.B.3.a; III.A.2) 
leads its younger members into alcoholic or other escapades away from the campus, the Code principle of University concern with protecting persons "in the University community" rather than with the locus of misconduct can still furnish the policy test for Code coverage; but the academic conmunity is sometimes divided not only on the limits of its responsibility but, just as the wider adult society, on the seriousness of society's rules in such matters.

Before the new Code system had time to work out the policy toward group sanctions and other early adjustments, the whole program faced sudden catastrophe. Fiction could hardly have contrived a challenge more directly testing each of the premises of the Code as well as the University's determination to stand by them.

In May 1964 the press and news broadcasts in Oregon reported that a major sex scandal involving University students had been under investigation since November by Eugene police and by a grand jury. "JURY BLAMES U.O. STUDENTS IN SEX CASE" proclaimed headlines in The Oregonian on May 2, "30 Condemned for Immoral Conduct Involving Girl, 13; College Action Due." The grand jury returned no indictments, the report explaimed, to avoid numerous court appearances by the girl that would jeopardize her rehabilitation.

The grand jury recommended University officials study the evidence and take disciplinary action against the students.

"This would make it possible for students to be held accountable for immoral conduct," and irreparable damage would not be done to the girl, the jury report stated. . . .

Dist. Atty. Frye said the offenses involved nore than one form of sexual misconduct, and occurred in motels, cars, apartments, and iu one fraternity house. ${ }^{35}$

To deal with another ambiguity of the relationship between the University and student living organization, an amendment holds a group responsible nnder the group offenses section with respect to conduct of one of its residents who may not be registered as a student and thus not himself under Code jurisdiction. (III.D.2)

${ }^{35}$ The Oregonian, May 2, 1964, p. 1, col. 1. Further details appeared in the local newspaper. According to the girl, who had shared the initiative in arranging a series of incidents over several months, two episodes had occurred "on campus," in a fraternity house in one night. "One involved between nine and 16 students, accordimg to her account." The District Attorney had joined with the grand jury's decision not to indict. But the legality of the grand jury report was doubtful. "Judge Roland Rodman . . . acknowledged that he bad some questions about it. ... 'There's a very good question about whether a grand jury is authorized to make this type of report ...." Eugene Register-Guard, May 10, 1964, p. 1, col. 1.

Oregon law authorizes grand juries only to "inquire into all crimes committed or triable in the county and present them to the court, either by presentment or indictment ...." ORE. Rev. Stat. \& 132.310 (1965) (Presentment means exclusively to ask the court for instruction on the law applicable to facts presented to the court without mentioning the names of individuals. ORE. REv. STAT. \& 132.370 (1965).); cf. the decision of the New York 
During the following days, the grand jury's general charge of widespread sexual misconduct at the University, and its demand for University discipline in the specific cases reported, made the still-struggling new Code system front page material. Reports on the campus scandal, with accompaniment in the letters-to-the-editors columns, appeared side-by-side with articles about the impending public vote on the 30 million dollar bond issue for state college buildings.

The University had cooperated with the police in the investigation; now that there were to be no prosecutions the burden fell on the first Student Conduct Committee. The University appointed a special attorney to help in the preparation of the proceedings, and the students involved were told of their right to do likewise. There was widespread pessimism whether the University administration could ultimately do anything but reassert authority to take direct action against the accused students even though the Code would be destroyed in the process.

Yet the prospect was not wholly bleak. The different settings for university policy decisions in Oregon and in California are perhaps illustrated by contemporaneous editorial comment. Under the heading "The 'Lolita' Case and Equal Justice," the Eugene Register-Guard wrote:

The University of Oregon has been given a choice. Would it rather boil? Or fry?

The University should reply that it cares neither to boil or fry. It should toss the whole mess back to the district attorney. . . . The University should refuse to clean up what civil authorities have so unctuously refused to handle. ${ }^{36}$

The Oregonian seconded the criticisms of the Register-Guard, concluding: "The grand jury failed in its responsibility." at the apparent delinquencies committed, there was little acceptance of the grand jury's assumption that, unlike a court, the University could punish the wrongdoers without further examination of the unfortunate chief witness.

Court of Appeals ending the practice of grand jury reports as unauthorized by law: "An indictment... is but the first step in a long process in which the accused may seek vindication through exercise of the right to a public trial, to a jury, to counsel, to confrontation of witnesses against him and, if convicted, to an appeal. A report, on the contrary ... charges the violation of subjective and unexpressed standards of morality and is the first and last step of the judicial process. It is at once an accusation and a final condemnation... [and] carries the same sense of authoritative condemnation as an indictment does, without, lowever, according the accused benefit of the protections accorded to one who is indicted." Wood v. Huglies, 9 N.Y.2d 144, 154; 212 N.Y.S.2d 33, 39-40; 173 N.E.2d 21, 26 (1961).

36 Eugene Register-Guard, May 11, 1964, p. 12A, col. 1.

37 The Oregomian, May 18, 1964, p. 22, col. 1. 
The rest of the drama is drily summarized in the first annual report of the Student Conduct Committee, though not the hours of painstaking legal labor of the part-time, amateur, academic, and student judges that preceded it:

Prior to evaluating evidence in the case, the Committee decided policy and procedural questions as follows:

a. The Committee took original jurisdiction over the investigation under Sub-Section I-E-5 of the Conduct Code.

b. It was agreed that the Committee was not concerned with whether crimes had been committed, that being the function of the regular criminal courts.

c. It was further agreed that no action should be taken in any case which did not meet the jurisdictional and procedural requirements of the Conduct Code, particularly Sections I-A-2, 3, and 4. In other words, a case must constitute a violation of the Code itself rather than a violation of criminal law. It must also "directly and significantly interfere" with stated University responsibilities. Finally, no action should be taken unless the accused student was provided with the procedural safeguards established by the Code.

The Committee's discussion preceding these decisions was conducted with a view toward establishing precedent for future possible actions.

The police investigation report of the matter was furnished to the Committee by the District Attorney and reviewed by the Committee to determine which cases met the agreed criteria. Many failed to meet the requirements of Section I-A-3 of the Conduct Code but charges were filed against some students and hearings commenced thereon. It soon became apparent that these cases could not be disposed of without taking the testimony of the girl involved and giving the accused students an opportunity to confront and cross-examine her. When these cases were being heard a clear case of mistaken identity was discovered in the record. This, plus the impossibility of meeting the procedural guarantees provided in the Code, convinced the Committee that further action was impossible without testimony from the girl imvolved in the case. A University request that the girl be ordered to appear before the Committee was refused by the Circuit Court of Lane County and the Committee then unanimously agreed that it must suspend its investigation. ${ }^{38}$

38 University of Oregon Student Conduct Committee, supra note 30, at 4-5. Some perspective of the dimensions of the disciplinary program discussed herein, apart from a single dramatic incident, can be gained from the annual reports of the Student Conduct Committee. The first year under the Code (1963-64) saw 35 cases in the Student Court (one-third academic dishonesty) and 209 in the minor courts, the bulk of them involving closing hours and other dormitory regulations. The figures for 1964-65 were 23 cases heard (of 30 charged) in the Student Court, 234 in the minor courts, involving mostly closing hours and possession of alcolrol. The sanctions included 7 suspensions in 1963-64 and 5 in 1964-65; all, except for one case of theft, imposed for cheating, plagiarism, or falsification of records. Disciplinary probation (which does not involve interruption of academic stand- 
The higher education bond issue was approved by the voters in the May election.

\section{III}

SOME REFLECTIONS ON CAMPUS LAW

A host of questions are raised today, from very different angles of vision, about the phenomena of mass higher education and the new student activism in the United States-phenomena distinguished as subjects of analysis by their own output of diverse and highly articulate selfanalysis. In this context, discussion couched in the concepts and vocabulary of any one discipline risks being dismissed as narrow, unreal, or irrelevant by all the other audiences across the spectrum from the politicians, the press, and the alumni, through the academic administrators, the social scientists, and the less professionally yet equally voluble faculty commentators, to the theoreticians and tacticians among the students themselves. Law professors, in particular, are suspect among practicing lawyers as academicians, and in the academy as Philistines. With this caveat, a law review symposium on student protest nevertheless calls into the foreground reflections on the role at the modern university of the law's values and techniques.

One man's experience at the University of Cahifornia at Berkeley and the University of Oregon in Eugene nets this miscellaneous collection of truths and fictions about law on the campus.

It is a fiction that the management of student discipline is a task beyond the capabilities of a university faculty, an assertion of ten made at Berkeley and in opposition to adoption of the Code in Eugene. Professors can be judges-sometimes awkwardly, and certainly with regret for the investment of professional time and energy diverted, but nevertheless fairly and effectively. A faculty can legislate disciplinary policy and rules, through committees and finally by decision in whatever general forum its organization provides. To perform these functions at a large university, obviously a faculty needs the aid of administrative personnel and services; but the confidence inspired in students by the principle of faculty supervision of serious disciplinary sanctions need not be sacrificed. A faculty inay not want that responsibility, or the law may not provide for it, but it is not inherently unworkable.

ing) was imposed 45 times the first year and 100 times the second. The police reported totals of 100 police cases involving 150 students in 1963-64, and 140 cases involving 235 students in 1964-65, the largest single item in each year being liquor offenses.

For checking the correctness of my account of the Code and its history, though not of my opinions, I am indebted to three colleagues at the University of Oregon School of Law who were, respectively, its chief draftsman and the first and second chairmen of the Student Conduct Committee, Professors C. D. Clark, F. R. Lacy, and W. M. Basye. 
It is a fiction that no university code can adequately inform students of all rules duly adopted that carry disciplinary sanctions, and limit all discipline to infractions of rules so adopted and stated, without including some very general catchall rule of good conduct to cover a myriad of unanticipated forms of bad behavior. Sucli a claim reflects more indignation that bad conduct may escape university sanctions-the urge to punish -than conceru with any clearly understood institutional need. True, some highly dehinquent students may evade code sanctions (though not legal prosecution) while a code rule is drawn or amended; but the university will likely survive. Lawyers, at least, have accepted occasional nonpunishment as a commonplace cost of nulla poena sine lege in the wider social order ever since the expandable generahities of common law were abandoned for statutory crimes.

Another fiction is the value ascribed to a state university's institutional status under the state constitution as a gnarantor of academic independence. In California, the University's supposed imdependence of secular politics under the Cahfornia constitution has been argned as a premise for bauning pohtics from the University-a reversal of principle unknown at the University of Oregon, which is wholly a statutory creation. ${ }^{39}$ Perhaps a sympathetic court could cite constitutional establishment to protect a courageous university against pohtical retaliation in all but its finances-but given this exception, how reahstic is the prospect of litigating the issue of independence? The first hine of defense, and probably the last, lies in the pohitical tradition and setting of the university in the state, and in the convictions, the responsibility, and the courage of its defenders in press and politics, alumm and administrators, faculty and students. The University of Oregon has no special immunity or insurance for the future; but so far Oregonians, unlike their southern

80 The Introduction of the University of California's official statement of policies relating to students and student organizations until July 1, 1965, recited that "the University is required by Article IX, Section 9, of the California Constitution to be 'entirely independent of all political and sectarian infiuence and kept free therefrom in the appointment of its Regents and in the administration of its affairs,' and lence University facilities and the name of the University must not be used in ways which will involve the University as an institution in the political, religious, and other controversial issues of the day." University of California, Policies Relating to Students and Student Organizations 2, Sept. 1963, reprinted in California Monthly, Feb. 1965, pp. 76-77. The "hence" in his syllogism turned a constitutional clause designed to protect the University's freedom against political pressures and reprisals into a legal limitation on freedom to pursue "controversial issues of the day," an absurd result if it were applied to the academic research and teaching functions. The word "required" does not appear in article IX, § 9; the constitutional command that "the University slabll be entirely independent" is plainly addressed to those wlio would impose political or sectarian influence, not to the prospective victim. Beyond this, the equating of "University facilities" and the "University name" is particularly questionable. 
neighbors, have not seen bitter pohtical issues in the existence of freedom of speech or fair disciplinary procedures on their University campus.

\section{The Case for Law}

Apart from institutional independence, however, constitutional premises are important to campus law for student conduct, whether political or not. These premises demand recognition of the rapidly changing constitutional position of public functions in the inodern state. ${ }^{40}$

In more difficult matters than law, mass higher education today strains the traditional identity of the university. It struggles to save the values of the academic community of scholars. The intellectual model may still derive from Padua and Oxford; but when a state like California can reasonably foresee serving one million students in public higher education, the legal model is the social service agency and the public building complex-not the ivied embrace, at once protective and exclusive, of alma mater. The university must be prepared to deal with the student at arms length. The change is crucial for the concept of university discipline. An ancient malcontent who throws a brick througin the window of the social security office, a group of workers staging a sit-in for unemployment checks, a veterans' organization picketing a V.A. hospital, may each commit some punishable offense-but they do not ipso facto give the administering agency cause to terminate their eligibility under these programs. The Department of Justice recently explained to General Hersley that even unlawful forms of protest against military service in Vietnam do not subject the protestor to reclassification under selective service. ${ }^{41}$

In each example, legal standards of eligibility and its loss are founded in relevance to a person's suitability for the program, not in disciplinary purposes. Quite obviously, they will be different in the case of educational programs. But whatever standards of behavior may arguably be defended as relevant to suitability for pursuing courses at a public college, the concept excludes a good deal of what still is widely considered customary university supervision of student conduct. And beyond substantive relevance, the public-service model also demands that standards of disqualification be publicly adopted and stated, with reasonable precision, in advance of their application, and be applied with some assurance of

40 I have discussed elsewhere what I believe to be the governing constitutional premises. Linde, Constitutional Rights in the Public Sector, 40 WASE. L. REv. 10 (1965). See also Cole, Linde, \& O'Neil, Memorandum to tbe Committee on Academic Freedom of the Berkeley Division, Dec. 1964, reprinted in TrIe Berketey Student Revort 273 (Lipset \& Wohin eds. 1965); O'Neil, Some Reflections on the Academic Senate Resolution, infra this symposium.

41 N.Y. Times, Jan. 12, 1966, p. 1, col. 1 (city ed.). 
procedural regularity and fairness. As one consequence, the state university's management of its campus, student activities, and student discipline must more than before draw on and use good legal advice. That means something more than the negative task of determining what past judges have or have not let college administrators do, more than reliance on some supposed common law of schools gathered from cases scattered over many decades and jurisdictions, more than suggesting noncompliance with the paperwork of an administrative procedure act until a court someday should require it. It means problem-solving im the light of a legal look forward, not backward; helping administrators distinguish whether they are making rules in their educational responsibility for students (not dependent on campus boundaries) or as managers of public property (concerned with users and visitors besides students) ${ }^{42}$ recoguizing that $E d w a r d s^{43}$ and Sherbert ${ }^{44}$ of 1963 , though concerned with Negro demonstrators and unemployment compensation, may have greater pertinency than Hamilton ${ }^{45}$ of 1934 , though it dealt with the University of Cahifornia.

Beyond doubt, the legalism of student rights in the public-service model of the state university has its costs. It accelerates, just as it reflects, the erosion of traditional and valued forms of the academic community. We can understand the nostalgia of the alumnus recalling an unplanned departure froin Old State on advice of kindly Dean Flintheart, even if we do not share his indiguation at the present presumptions of the young. But legalism is an inevitable price of mass operation. The cost can be, at the least minimized, and at best turned into genuine reform, if the concept of the academic community is itself nuade the guiding principle and essential premise delimiting the university's concern with student conduct. That is what the University of Oregon's Code has souglit to do.

Finally there is a case for law that transcends the demands of legality, that makes Oregon's experiment relevant beyond the conventional disciphinary tasks at Eugene to the nore radical student challenge of the multiversity.

That challenge proclaims and protests against a vision of late twentieth-century society of which the irritations and frustrations of the mass

$42 \mathrm{Cf}$. note $40 \mathrm{infra}$. That student claims to administrative regularity are modern issues also beyond the writ of the Constitution is illustrated by a recent report of student protests at Marburg, Germany, where the dormintory management evicted, without notice or administrative procedures, a coed found in bed with a young man by a housekeeper who had burst into the girl's room at an unexpected hour. Die Zeit, Feb. 8, 1966, p. 7.

43 Edwards v. South Carolina, 372 U.S. 229 (1963).

44 Sherbert v. Verner, 374 U.S. 398 (1963).

45 Hamilton v. Regents of the Univ. of Cal., 293 U.S. 245 (1934). 
university are only symptonatic. It does not matter here whether the vision and the protests have merit. But the student generation that shares in then also shares with civil rights and other protest movenients, from which the new student activism has drawn both mystique and techmique, an implicit assumption of the hostility of the law. Though they will appeal to the ultimate legal guarantees of the constitutional Bill of Rights, they expect from law and legal procedures only that they will prove to be tools in the hands of the establishment.

Campus law too often, and unnecessarily, confirms this pessimistic assessment, and in the process discredits both law and the good faith of administrators. True, under the pressures of total distrust and an implacably adversary confrontation no words in a faculty resolution, an administrative agreement, or a code, even Oregon's, provide foolproof guarantees. The more reason that a wise university will hold itself strictly within the law of the campus, and give the benefit of any ambiguities to the student rather than exploiting them for itself-a principle we think elementary in construing an insurance policy-even if it means failure in some painful episode.

For if the object is to secure respect for law, to lose a battle may be to win the war. It is not perfection of wording that sustains student confidence in the Oregon Code; it is the sincerity of the effort, the commitment to fairness. If the same is what lawyers would claim for law in society, we should insist on it at the universities. In the university's confrontation with the perennial challenge of the questioning and the angry, the goal is not to convert the last-ditch revolutionary, or the insidedopester who guards in his cymicism his only source of identity, or the true believer in creative disorder. It is to offer the majority, with genuine respect for the radical skepticism of every younger generation, persuasive demonstration of the alternative of law as a way of creative order. 


\title{
APPENDIX \\ University of Oregon Student Conduct Program
}

\author{
Published as Revised July 1, 1965
}

\section{THE CODE OF STUDENT CONDUCT}

\section{A. General Policies}

1. The University is dedicated not only to learning and the advancement of knowledge but also to the development of ethically sensitive and responsible persons. It seeks to achieve these goals through a sound educational program and policies governing student conduct that encourage independence and maturity.

2. The University distinguishes its responsibihty for student conduct from the control functions of the wider community. When a student has been apprehended for the violation of a law of the community, the state, or the nation, the University will not request or agree to special consideration for the student because of his status as a student. The University will cooperate fully, however, with law enforcement agencies, and with other agencies in any program for the rehabilitation of the student. Ordinarily, the University will not impose further sanctions after law enforcement agencies or the courts have disposed of a case.

3. The University may apply sanctions or take other appropriate action only when student conduct directly and significantly imterferes with the University's (a) primary educational responsibility of ensuring the opportunity of all members of the University community to attain their educational objectives, or (b) subsidiary responsibilities of protecting the health and safety of persons in the University community, maintaining and protecting property, keeping records, providing living accommodations and other services, and sponsoring non-classroom activities such as lectures, concerts, athletic events, and social functions.

4. Procedural fairness is basic to the proper enforcement of all Umiversity rules. In particular, no disciplinary sanction as serious as expulsion, suspension, disciplinary probation, or entry of an adverse notation on any permanent record available to persons outside the University shall be imposed unless the student las been notified in writing of the charges against him and has had an opportunity (a) to appear alone or with any other person to advise and assist him before an appropriate committee, court, or official; (b) to know the nature and source of the evidence against him and to present evidence in his own behalf, and (c) to have his case reviewed by the Student Conduct Committee.

5. Students shall have an opportunity to participate fully in the formulation of all policies and rules pertaining to student conduct and in the enforcement of all such rules.

6. Rules and sanctions affecting the conduct of men and women shall be based on general primciples of equal treatment, mcluding like penalties for like violations.

\section{B. Violations}

1. No sanction or other disciplinary action shall be imposed on a student by or in the name of the University except in accordance with this Code.

2. Expulsion or suspension from the University or any lesser sanction may result from the commission of any of the following offenses: 
a. Academic cheating or plagiarism

b. Furnishing false information to the University with intent to deceive

c. Forgery, alteration, or misuse of Umiversity docunients, records, or identification cards

d. Physical abuse of another person in the University community

e. Malicious destruction, damage, or misuse of University property, including library niaterials, or of private property on the campus

f. Theft occurring under the conditions of paragraph A-3

g. Vandalism or kidnapping committed on other campuses

h. Participation in hazing

i. Lewd or indecent conduct occurring under the conditions of paragraph A-3

j. Two or nore (or the repetition of) offenses listed in paragraph 3 below

3. Disciplinary probation or any lesser sanction nuay result from the commission of any of the following offenses:

a. Possession, consumption, or furnishing of alcoholic beverages on University owned or controlled property (except in living quarters of married students), in University related housing for single students, or at University sponsored or supervised functions

b. Disorderly conduct, including disorderly conduct resulting from drunkenness, occurring under the conditions of paragraph A-3 (As amended by the faculty June 12, 1964)

c. Raiding of University related living units

d. Violation of closing hour restrictions

e. Violation of visiting hour rules

f. Violation of any University rule approved by the Student Conduct Committee for the infraction of which sanctions may be imposed under this Code.

4. All rules approved by the Student Conduct Committee pursuant to paragraph 3 (f) shall be in writing and shall be published, distributed, or posted in such a manner as to furnish adequate notice of their contents to students affected by such rules. The University's failure to comply with this requirement shall be a complete defense to any charge of violation of a rule of which the student has no actual knowledge.

\section{Sanctions}

1. Sanctions which may be imposed for the comnission of University offenses shall include the following:

a. Expulsion from the University

b. Suspension from the University for a definite or indefinite period of time

c. Disciplinary probation with or without loss of designated privileges for a definite period of tine. The violation of the ternis of disciplinary probation or the infraction of any University rule during the period of disciplinary probation nuay be grounds for suspension or expulsion from the University. The parents of any student under 21 years of age who is placed on disciphinary probation, suspended, or expelled shall be so notified.

d. Loss of privileges:

1. Restriction to campus living quarters

2. Denial of use of an automobile for a designated time 
3. Removal from dormitory or other University housing

4. Loss of such other privileges as may be consistent with the offense committed and the rehabilitation of the student

e. Admonition and warning

f. Such other sanctions as may be approved by the Student Conduct Committee

2. The sanctions of expulsion or suspension shall not be imposed except upon proper determination by the Student Court or the Student Conduct Committee.

3. The General Policies, Violations, and Sanctions shall be printed and made readily available to all students. The campus newspaper shall be requested by the Student Conduct Committee to publish the same at the beginning of each school year.

\section{Group Offenses}

(Adopted by the Student Conduct Committee December 20, 1963, in part II of the Code of Student Conduct, pursuant to part I, E4 of the Code. Adopted as a part of part I of this Code by the Faculty on February 5, 1964)

1. Living organizations, societies, clubs and similar organized student groups are responsible for compliance with law and University regulations. Upon satisfactory proof that the group has encouraged or did not take reasonable steps, as a group, to prevent violations of law or University regulations, the group may be subjected to permanent or temporary suspension of eharter, social probation, denial of use of University facilities, or other like sanctions.

2. The determination that a group is liable to sanction under the foregoing section 1, and of the sanction to be imposed, shall be made by the Student Conduct Committee at a hearing held for that purpose. The president, or principal officer, of the group must be given reasonable notice of the time and place of said hearing and of the nature of the charges. He, and any other member of the group, are entitled to attend and be heard at the hearing.

3. Nothing herein authorizes the imposition of individual sanctions on any person other than in accordance with the Code of Student Conduct.

\section{E. The Student Conduct Committee}

1. The Student Conduct Committee, by faculty legislation and by delegation of the President of the University, is designated as the agency within the University which has primary responsibility for the student-conduct program. The Committee shall be responsible to the faculty and the President of the University for recommending policies relating to student conduct, for fornulating or approving rules and enforcement procedures within the framework of existing policies, for disposing of such individual cases as may properly come before it, and for recommending to the President of the University changes in the administration of any aspect of the student-conduct program.

2. The Committee shall consist of four faculty members and three student members. ...

$\cdots$

4. All regulations or rules relating to student conduct that are establislied by any university official, committee or student group, and for which sanctions may be imposed in the name of the University, must be submitted to the Committee 
for approval. Such written regulations or rules shall be effective fifteen days after filing with the Secretary of the Committee unless disapproved, within this period, by the Committee. Fraternity, sorority, or Co-op "housekeeping" rules adopted by members for the internal manageinent of the living unit are not considered University rules for the purpose of this Code.

5. The Committee may delegate jurisdiction to handle infractions of University rules to the Student Court and such other tribunals as may be established. With the consent of the President of the University, the Committee also may delegate such jurisdiction to appropriate University officials. In all instances such jurisdiction shall be defined by the Committee, ordinarily in terms of specified offenses, maximum sanctions, or designated living units. The Committee may at its discretion withdraw delegation of jurisdiction in any case and dispose of such case itself.

6. The Committee shall require from University officials and tribunals periodic written reports of the disposition of all student-conduct cases handled under their jurisdiction. The gathering of such reports and their submission to the Committee shall be the responsibility of the Associate Dean of Students. The Committee shall examine such reports for consistency with existing policies and, where necessary, review the reports with the appropriate officials or tribunals.

7. The Committee shall-submit to the faculty and the President of the University, each Spring term, a written report covering the entire student-conduct program, including an evaluation of existing rules, policies, and enforcement procedures. It shall recommend changes in policy to the faculty and the President and changes in the administration of the program to the President.

\section{F. Student Tribunals}

1. The Student Court shall be composed of five students and two faculty nembers, each appointed by the President of the University. The student members shall be recommended by the President of the Associated Students. The jurisdiction of the Student Court and its procedural rules shall be established or approved by the Student Conduct Committee.

2. The Student Conduct Committee, with the assistance of the Associate Dean of Students, may establish minor tribunals composed of students. When appropriate, University officials or faculty nembers inay serve as advisors. No mimor tribunal shall have jurisdiction to impose the sanction of expulsion or suspension.

3. No tribunal shall have any function except the enforcement of University rules or the performance of other duties which may be delegated to it by the Student Conduct Committee.

\section{G. Records}

\section{H. Amendments}

1. The above Code may be amended only by action of the general faculty of the University of Oregon. 


\section{THE ADMINISTRATION OF THE CODE}

\section{A. The Student Court}

4. The Court shall maintain, with the assistance of the Associate Dean of Students, an adequate record of the history and disposition of each case to come before it. The record shall include a summary of the evidence upon which the Court based its decision.

7. Any student whose case is referred to the Court shall be notified of such referral in writing by the Associate Dean of Students at least three days before the hearing and shall be apprised in the notice of the charges against him. During the hearing the student shall have the opportunity (a) to appear in person or through counsel, (b) to know the evidence against him, and (c) to present evidence and argument in his own behalf. A request by a student for a hearing closed to the public will be given due consideration. In the resolution of factual disputes, the Court will request the testimony of witnesses and otherwise seek the best evidence obtainable.

8. The Associate Dean of Students shall make available to the Court any information relevant to the case, assist the Court during the hearing, and advise the Court of relevant precedents. He shall not, however, sit with the Court during its deliberations in closed session.

10. Rutes of Procedure (adopted by the Sudent Conduct Committee November 4, 1963)

a. Notice.

b. Outline of Proceedings.

1. Student does not appear....

2. Student not reasonably able to appear....

3. Student appears personally or through representative. . . .

...

c. Evidence.

1. Hearsay evidence....

2. Other evidence. Except as provided in the case of hearsay evidence any evidence that the Court believes is relevant is admissible.

3. Record. The chairman, or another member of the Court, shall make a record of the substance of each witness's testimony.

d. Objections and motions.

e. Decisions of the Court.

1. Vote required. A decision that a student has committed an offense requires an affirmative vote of two-thirds of the members of the Court deciding the case....

...

f. Standard of Proof.

1. No member of the Court shall vote that the student has committed 
the offense as charged unless the evidence is clear and convincing to him.

g. Appeal.

\section{General Procedures}

7. The Associate Dean of Students will keep a record of the nature and disposition of all cases brought before the courts. This record will not contain names of students. A second file will be kept, listing students brought before courts alphabetically with a cross-reference to the record of cases. Entries in this last file will be removed when the student graduates or five years after he leaves school. (Adopted by the Student Conduct Committee June 2, 1964)

8. In all instances imvolving a reported alleged violation of the code where the Associate Dean of Students does not refer the case to the Student Court or an appropriate minor judicial tribunal for action, the Associate Dean of Students shall make a full report of the basic facts and the reasons for the non-referral for judicial proceedings to the Student Conduct Committee. (Adopted by the Student Conduct Committee February 9, 1965.)

\section{E. Appeal Procedures}

3. The Student Conduct Committee shall serve as the appellate tribunal to hear appeals from the Student Court.

7. The Student Conduct Committee may review on its own motion a decision of any judicial tribunal or counselor in any case regardless of the sanction imposed. The procedure outlined immediately above shall govern the conduct of such a review.

\section{RUI.ES AND REGUI.ATIONS}

